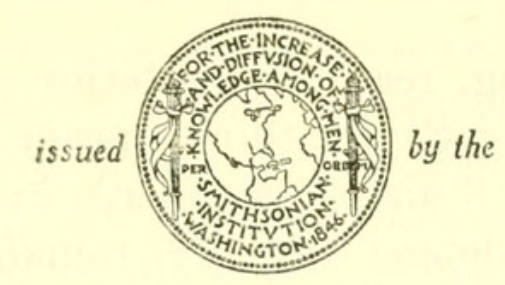

SMITHSONIAN INSTITUTION

U. S. NATIONAL MUSEUM

Vol. 84

Washington: 1937

No. 3016

\title{
TWO NEW BEETLES OF THE FAMILY MORDELLIDAE FROM ORCHIDS
}

By Eugene Ray

THe descriptions of mordellid beetles herein make available for reference the names of two new species of Mordellistena taken in the leaves of orchids. A previously described species (M. cattleyana Champion ${ }^{1}$ ) has been collected from the flower of Cattleya sp. The present paper extends the known habitat of the genus to include the orchid genera Epidendrum and Cailloga.

\section{Genus MORDELLISTENA Costa}

\section{MORDELLISTENA EPIDENDRANA, new species}

This species may be separated from cattleyana Champion by the absence of the two transverse, fuscous, elytral fasciae, the broader terminal segment of the maxillary palpi, and the different number of ridgelike rows of short black setae on the posterior tibiae and tarsi.

Length: $2.5 \mathrm{~mm}$; including anal style, $3.2 \mathrm{~mm}$. Elongate, subparallel. Derm bicolored; head piceocastaneous (a narrow line along occiput and a broad circular area along front fuscocastaneous in female); pronotum flavocastaneous; a vague cloud visible in some specimens at center of base; scutellum fuscopiceous; elytra castaneous, with suture and lateral margins narrowly fuscous-in the male the fuscous coloration includes the entire apical half of

\footnotetext{
1 Ent. Monthly Mag., vol. 49, p. 56, March 1913.
} 
elytra; ventral surface flavocastaneous (castaneous in male), side pieces of mesosternum darker; anal style fuscous (piceous in male); apical setae and ridges of legs piceous; antennal segments fuscocastaneous. Body densely covered with fine, recumbent, flavocinereous pubescence.

Antennae $0.5 \mathrm{~mm}$ long, reaching posterior coxae; segments 1 and 2 equal; 3 and 4 equal, each one-third shorter than $2 ; 5-10$ equal in length, each as long as 3 and 4 together, strongly convex on mesal margin; 11 one-fourth longer than 10, rounded, attenuate to apex. Apical segment of maxillary palpus enlarged, broadly scalene-triangular, sides slightly curved, corners rounded. Prothorax slightly broader than long, sides rounded, basal angles acute, base arcuate, midbasal lobe short, rounded. Scutellum small, triangular. Elytra two and one-half times as long as broad, sides subparallel, apical third strongly curved, apices individually rounded. Posterior tibiae with two equal oblique ridges extending halfway across outer face; posterior basitarsus with two, second segment with two oblique ridges. Anal style more than two and one-half times as long as apical ventral segment, moderately slender, evenly attenuate, truncate at apex.

Type locality.-Dominican Republic.

Type-Male, U.S.N.M. no. 51950.

Remarks.-Four specimens, one male, three females, are at hand. All were secured in Epidendrum sp. from the Dominican Republic on September 10, 1936, at San Francisco, Calif., the port of entry. As noted above, the only differences between the sexes is the generally darker color of the male.

MORDELLISTENA CHAPINI, new species

This species may be separated from both cattleyana Champion and epidendrana, described above, by the peculiar coloration of the derm and pubescence on the elytra, the different color combinations of the entire body, the club-shaped terminal segment of the maxillary palpi, the single ridge on the second segment of the posterior tarsi, the slenderer, peculiar antennae, and the smaller size.

Length: $2.2 \mathrm{~mm}$; including anal style, $2.7 \mathrm{~mm}$. Elongate, subparallel. Derm bicolored; head and pronotum fuscocastaneous, the latter with a mediodorsal cloud; humeri of elytra with a broad, circular, humeral spot, extending one-fourth entire length, not touching suture; anterior and intermediate legs flavous, antennae, maxillary palpi, and posterior legs fuscoflavous. Body densely covered with fine, recumbent pubescence, partaking of ground color, except on elytra, where there occurs postmedially a broad, transverse, arcuate band (broadest anteriorly at suture) and a large apical area covering apical sixth. 
Antennae $0.4 \mathrm{~mm}$ long, reaching posterior coxae; segments 1 and 2 equal; 4 distinctly longer than $3 ; 5-10$ each one-half longer than 4 , subfiliform, slender; 11 longer than 10, rounded, attenuate to apex. Apical segment of maxillary palpus enlarged, club-shaped, broadest subapically, mesal margin strongly curved, lateral margin straight, apex abruptly rounded. Prothorax broader than long, sides rounded, basal angles right angles, base arcuate, midbasal lobe short, rounded. Elytra more than two and one-half times as long as broad, sides subparallel, apical third strongly curved, apices individually rounded. Posterior tibiae with two equal, oblique ridges extending halfway across outer face; posterior basitarsus with two, second segment with one oblique ridge. Anal style two and one-half times as long as apical ventral segment, slender, evenly attenuate to apex.

Type Tocality.-Venezuela.

Type.-Male, U.S.N.M. no. 51951.

Remarks.-Two specimens, both males, are at hand. The type emerged from a leaf of Cattleya sp. from Venezuela, on May 15, 1936, at Washington, D. C., in quarantine, The paratype was taken as a leaf miner in Cailloga sp. from Brazil and emerged on August 11, 1936. The latter specimen bears the provisional determination label of Mordellistena cattleyana (?) Champion but is undoubtedly identical with the type of chapini. This species is named for Dr. Edward A. Chapin, of the Smithsonian Institution. 


\section{$2 \mathrm{BHL}$ Biodiversity Heritage Library}

Ray, Eugene. 1937. "Two new beetles of the family Mordellidae from orchids." Proceedings of the United States National Museum 84(3016), 239-241. https://doi.org/10.5479/si.00963801.3016.239.

View This Item Online: https://www.biodiversitylibrary.org/item/32837

DOI: https://doi.org/10.5479/si.00963801.3016.239

Permalink: https://www.biodiversitylibrary.org/partpdf/4224

\section{Holding Institution}

Smithsonian Libraries

\section{Sponsored by}

Smithsonian

\section{Copyright \& Reuse}

Copyright Status: NOT_IN_COPYRIGHT

Rights: https://www.biodiversitylibrary.org/permissions/

This document was created from content at the Biodiversity Heritage Library, the world's largest open access digital library for biodiversity literature and archives. Visit BHL at https://www.biodiversitylibrary.org. 